\title{
Casting the Lean Spell: The Promotion, Dilution and Erosion of Lean
}

\section{Management in the NHS}

Leo McCann, John S Hassard, Edward Granter and Paula J Hyde

Accepted for publication in Human Relations, vol 68, no 10, 1557-1577

DOI: 10.1177/0018726714561697

\begin{abstract}
Lean thinking has recently re-emerged as a fashionable management philosophy, especially in public services. A prescriptive or mainstream literature suggests that lean is rapidly diffusing into public sector environments, providing a much-needed rethink of traditional ways of working and stimulating performance improvements. Our study of the introduction of lean in a large UK public sector hospital challenges this argument. Based on a three year ethnographic study of how employees make sense of lean 'adoption', we describe a process in which lean ideas were initially championed, later diluted, and ultimately eroded. While initially functioning as a 'mechanism of hope' (Brunsson 2006) around which legitimacy could be generated for tackling longstanding work problems, over time both 'sellers' and 'buyers' of the concept mobilized lean in ambiguous ways, to the extent that the notion was rendered somewhat meaningless. Ultimately our analysis rejects current prescriptive or managerialist discourses on lean while offering support for prior positions which would explain such management fashions in terms of the 'life cycle of a fad'.
\end{abstract}

\section{Keywords}

Fads and fashions, fad life cycles; healthcare management, lean healthcare, lean production, NHS restructuring, Foundation Trusts. 


\section{Introduction}

Lean manufacturing (or 'lean') is one of the world's most influential management ideas. Champions such as high-profile gurus Womack et al (1990/2007) and Liker (2004) argue that lean principles are appropriate to all kinds of organization in both the public and private sectors. With origins dating back at least as far as early U.S. post-war process improvement and quality specialists such as W. Edwards Deming and Joseph Juran, the principles which later became adapted and promoted as 'lean

production' enjoyed considerable successes in the Japanese motor industry from the 1960s to today, exemplified by the Toyota Motor Corporation.

Lean is now widely promoted for use in public administration (Carter et al 2011). It has been enthusiastically adopted in many UK National Health Service (NHS) organizations in recent years (Waring and Bishop 2010), with some high-profile success stories claimed (Fillingham 2007). This paper investigates the introduction of lean principles in an NHS Foundation Trust hospital. It is based on an ethnographic exploration of how hospital staff encounter, discuss, accept, and in many ways resist lean adoption. The ways in which lean is packaged, understood, 'sold' and interpreted within the hospital raises important questions about the value of new or recycled managerial fashions, of employee reactions to them, and of their sustainability (Benders and van Veen 2001; Birnbaum 2000; Carson et al 1999, 2000; Newell et al 2001; Schofield 2001; Waring and Bishop 2010). 
We aim to add a critical element to the burgeoning literature on the adoption of lean into public sector settings. A mainstream prescriptive discourse suggests that lean is rapidly diffusing into public sector environments, providing a much-needed rethink of traditional ways of working and stimulating radical performance improvements (see Fillingham 2007; Radnor et al 2006; Radnor 2010). Other forms of research on lean adoption in the public sector take a different view, arguing that lean is fundamentally inappropriate to professional bureaucracies and is creating widespread dysfunction and employee disengagement (Carter et al 2011, 2013), or that lean is adopted superficially and ritualistically (Waring and Bishop 2010). The present paper pays specific attention to the micro-details of how lean is conceptualized and 'sold' in the hospital, and how and why staff 'buy', use, ignore, or reject lean principles. We explored the case for a period of three years, allowing us to explore the pliability of lean in practice and the vulnerability of its 'adoption' at the hospital over time (Benders and van Veen 2001; Schofield 2001). Rather than explicitly promoting or denouncing lean itself, the paper builds on and extends the analysis of Waring and Bishop (2010) concerning the indeterminacy of lean take-up in the NHS, adopting an ethnographic approach similar to that of Watson (1994: 898) in exploring how employees may be 'seeing value in much new thinking and language but hav[e] fears about what tends to be done with it in practice.' Our case analysis thus explores the ways in which lean is 'sold' in the hospital, how healthcare staff are 'buying' and 'using' it, and the longer-term outcomes, both for the hospital itself and for the concept of lean healthcare more broadly.

Our analysis proceeds in five further sections. We set the scene by providing a brief overview of the lean literature. Secondly we discuss the literature on management 
fads and fashions, specifically focussing on the notion of fad 'life cycles', arguing that this thread of literature remains highly pertinent to understanding the uncertainties of planned organizational change. Thirdly, we offer a description of the research methods of the study. This is followed by analysis of our ethnographic data structured around three themes: (i) lean promotion, (ii) criticisms and scepticism around lean in healthcare, and (iii) the processes whereby lean starts to erode. Finally conclusions are drawn about the appropriateness of lean in healthcare, and about the continued value of exploring organizational change through the lens of 'fad life cycles.'

\section{Lean in healthcare: Indispensable, exploitative or feeble?}

'Lean production' is basically a Western term (coined by American engineer John Krafcik - see Womack et al 2007: 11; Benders and van Bijsterveld 2000: 50-1) to describe the Toyota Production System (TPS), reputedly the brainchild of Taiichi Ohno and Shigeo Shingo, senior engineers who had long careers at the Toyota Motor Corporation from the 1940s (although this is disputed: see Coffey 2006). Fundamentally TPS / lean is about process improvement, specifically focusing on the identification and elimination of muda, or waste. Like all management 'fads and fashions' (Abrahamson 1991), lean promotion is a massive industry in itself. The most famous lean book is Womack et al.'s The Machine that Changed the World (1990/2007), which effectively introduced TPS and 'lean production' to Western audiences. Academic work is buttressed by a huge lean promotion industry, which features lean consulting companies as well as commentaries from managers of major companies (e.g. Wickens 1993). 
Womack and Jones, however, in the preface to Lean Thinking (1996: 12) are at pains to present lean not as a commercial fad but as a scientific discovery that will 'banish waste and create wealth'. Their work is highly detailed and very well-regarded in many industry and services circles; Machine that Changed the World is essentially the 'first-mover' before the later waves of lean promotion. Subsequent literature (especially after the coining and promoting of the term 'lean' by US consultants) makes sweeping statements about the undeniable power of lean, while also changing its meaning and expanding its scope (see below, and Coffey 2006).

As the concept has spread from manufacturing into services there is now a cottage industry just on the specific subject of lean adoption in healthcare (see for example Caldwell et al 2005; Eaton and Phillips 2008; Graban 2008; Radnor el al 2012). There are innumerable handbooks, how-to guides, consulting and training manuals, and conferences on how to 'revolutionize' healthcare delivery using lean systems. Radnor et al (2006), for example, strongly support the prospects for efficiency gains from lean adoption across the public sector. NHS policy documents proclaiming the need to adopt lean and demonstrating successful case studies have proliferated, and are widely available on the webpages of the Department of Health and at local hospital sites.

Amid the torrent of mainstream literature on lean as 'best practice' one can easily remain oblivious to lean's numerous critics. Firstly there is the 'humanitarian' critique, in which lean is associated with significant increases in work intensification and - contrary to the arguments of Womack and others - actually has no room for genuine worker involvement. Lean workplaces are just as demanding and 
authoritarian as Taylorian ones. There are many examples of the humanitarian critique of lean, among the most notable being Danford (1998), Delbridge (1998), Graham (1995), Kamata (1983), Mehri (2006), Milkman (1997), Stewart et al (2009); and Carter et al (2013).

The second, related, line of criticism is that lean is not a radical break with prior practice, but rather a form of 'perfected Taylorism' (Tamura 2006). These critics note that lean workplaces feature heavy standardization, rigid principles, tight statistical control, and the driving out of employee discretion, all three of which are staples of Taylorism. The difference with lean is therefore one of degree: several authors note that lean is indeed 'superior' to Taylorism but only in the narrow sense in that it eliminates waste, drives efficiency, and forces more effort out of workers in more efficient ways than in Taylorism (Tamura 2006). Plant-level studies by Milkman (1997) and Graham (1995) point to similar findings; despite the contrary promises of managers, lean actually replicates much of the old system of mass production. Examples of lean as 'perfected Taylorism' are provided by Japanese (e.g., Kamata 1983; Mouer and Kawanishi 2005; Tamura 2006) and UK/U.S. authors (e.g. Delbridge 1998; Graham 1995; Stewart et al 2009; and Carter et al 2011), and indeed many Toyota-affiliated engineers openly emphasize the consistency of TPS with Taylorism (Coffey 2006).

A third criticism of lean is that it is a fantasy construction. Lean's critics and/or sceptics (e.g., Mehri 2006, Williams et al 1994) and its more sober supporters (e.g., Wickens 1993) agree that lean retains many Fordist elements. It is, therefore, far from clear that describing lean as a radical break from the past - or a new 'one best way' - 
is sensible or accurate. [1] Coffey (2006), for example, argues that the Toyota Production system has never been about flexible specialization. Toyota's success has been won with highly standardized product offerings, but the facts have not been allowed to get in the way of the 'lean as flexibility' argument. In short, lean as a concept is highly malleable and contains elements of fantasy and exaggeration that do not survive close scrutiny, much like other pre-packaged managerial initiatives such as Six Sigma, TQM or Balanced Scorecard (Abrahamson 1996, de Cock and Hipkin 1997; Mills et al. 2009).

From the above, therefore, it would appear that lean has become a widely-promoted fad, based largely on a fantasy construction, that ignores or obscures the reality that lean is little more than an extension of Taylorism. Given this, one might argue that the literature on 'fads and fashions' is particularly instructive in developing an understanding of the continued popularity of the lean phenomenon. It is, therefore, to this literature that the discussion now turns.

\section{Fads, viruses and life cycles: Management fashions rebooted}

The literature on management 'fads and fashions' is wide and diverse and can be found within several disciplines and reflecting a range of conceptual positions. This includes, among others, somewhat straightforward writings warning managers of the dangers of 'fad surfing' (Ettore 1997; Furnham 2004; Gibson and Tesone 2001; Shapiro 1998), 'systematic' attempts to map fashion adoption/rejection trends (Abrahamson 1991, 1996; Carson et al 2000), historical analyses of the procession of management concepts (Huczynski 1993; Parker and Ritson 2005; Marcus 2008; 
Keulen and Kroeze 2012), empirically-informed case studies of the (typically ambiguous) practicalities of fad adoption (Brunsson 2006; de Cock and Hipkin 1997; Krause-Jensen 2011; Waring and Bishop 2010), and CMS-inspired deconstructions of the linguistic and rhetorical constituents of managerial concepts (Collins 2000; Grint and Case 2000; Kieser 1997). 'Fads and fashions' writings seemed to peak around the early-mid 2000s but, like management fashions themselves, there is always a 'fad residual' - they rarely disappear entirely (Birnbuam 2001: 196-213). Writings on fads have, indeed, returned in new forms, as for example in Røvik's (2011) suggestion that the metaphor of 'fashions' be replaced with that of 'viruses'.

This literature suggests that management fashions are ephemeral, of limited practical value, highly malleable, and short-lived (Carson et al 2000; Collins 2000: 33-4). Benders and van Veen (2001: 37-8; see also Benders and van Bijsterveld 2000) introduced the idea of 'interpretative variability', arguing that pre-packaged 'solutions' are deliberately vague and open to wide interpretation and translation by opportunistic 'adopters'. Similarly Brunsson (2006) describes change initiatives as 'mechanisms of hope' whereby both the 'selling' and 'buying' of a new management philosophy (such as lean) are understood as ritualistic performances. The content and results of organizational reform processes are of secondary importance to the generation of hope that the performance of reform generates in order to 'maintain the dream of the rational organization' (Brunsson 2006: 100). Hope can be irrational or 'a-rational' and appears to play a significant role in perpetuating the repeated and cyclical use of fads, even when so many seem to 'fail' or at least disappoint. 
A significant concept in the fads and fashions literature, therefore, is the "fad life cycle' (Birnbaum, 2000, 2001; Carson et al 2000) and in the current paper we specifically draw on Birnbaum's (2001: 126-132) 5-stage model [2]. The first stage is 'Creation', whereby a new management technology is proclaimed as the solution to a major crisis or set of changed circumstances. During this stage, the new management concept is heavily promoted by consultants, is advertised as an already proven system with a track record of success among early adopters (126), and is presented as universally applicable yet a serious system and not a 'technique of the month' (128). The second stage is 'Narrative Evolution' in which the fad spreads widely and becomes almost a norm among high-profile organizations (129). Consulting rhetoric presents the fad as superficially attractive and easy to adopt. Opponents are identified as 'resistant to change' (130). A third stage - a 'Time Lag' follows - a time before user reactions and independent analyses of the fad emerge. During this period cautionary tales start to circulate, the acceptance of the fad peaks, and the rate of adoption slows. Stage four is 'Narrative Devolution', in which scepticism and criticism overtake optimism and promotion, and the fad is 'declared a fraud' (131). Finally there is the fifth stage - 'Resolution of Dissonance' - in which promoters account for the 'failure' of their fad, typically blaming local management for botched adoption rather than considering any flaws in the fad itself. The fad is recycled with 'minor modifications' (132) and the Creation stage begins anew.

The NHS has been a late adopter of lean which is often the case with public sector fad adoption (Birnbaum 2001: 134-9). However lean was officially adopted with some vigour as a national NHS policy from around 2008 onwards. Our investigations of lean in the NHS began during the third stage of Birnbaum's cycle, the 'Time Lag' 
between vigorous promotion and the beginnings of the 'Narrative Devolution'. The 'Creation' and 'Narrative Evolution' phases had already occurred before we undertook this study, during the processes whereby lean was adopted as official national policy for NHS Trusts. But with the exception of Waring and Bishop (2010) there has been limited in-depth research into how lean has been promoted, received, implemented, interpreted, and possibly translated or rejected in the NHS. This paper provides such an examination of lean adoption at one case study English NHS hospital over a three-year period.

The fundamental research questions of our study were threefold. We wished to explore: 1) how lean was promoted at the hospital (in terms of what improvements were promised and why adoption was said to be required); 2) how and why staff claimed to have adopted and interpreted lean (and to consider how lean may have been adapted and translated in the process); and 3) how lean adoption was progressing (including employees' views on whether it will persist, change, or erode). As such, the research sought to explore how deep, effective and lasting the lean adoption had been, thus investigating the extent to which the story of lean in the case study hospital reflected concepts of a fad 'life cycle' (Birnbaum 2000, 2001).

\section{Research methodology}

Realities, meanings and ideologies

We explored lean adoption at Milltown Hospital through a combination of participant observation of lean training and awareness events and in-depth interviewing with 
managers and staff. A large amount of textual material on lean adoption in the hospital was also analysed, especially in terms of the visual techniques employed to promote lean.

The empirical information on which this paper is based was gathered from one of four NHS Trusts participating in a three year investigation into healthcare management funded by the National Institute of Health Research [3]. In each of our case organizations - a Foundation Trust (Milltown); an ambulance trust, a mental health trust and a now-abolished Primary Care Trust - we were given wide access for the purposes of carrying out interviews and ethnographic observations. The study investigated the 'daily realities' of managerial work and organizational change, focusing in particular on junior and middle managers, as these staff populations have considerable responsibility for managing people and processes. They were close to (and in many cases actually on) the front line of patient care so were able to provide very detailed information on how planned organizational change had 'filtered down' (or otherwise) to the actually daily running of patient care organizations. These managers were often holders of dual clinical/managerial roles, so issues of professional norms and values were prominent; many identified themselves as clinicians rather than as managers and were often sceptical towards managerialist discourses such as lean, and typically re-emphasized the importance of patient care and professional norms over managerialism wherever possible. This element added an interesting angle to the long-running conflict that middle managers in all large organizations face: they are at once managers yet also part of 'the managed' and the complexities of managerial work in this healthcare setting are further increased by their hybrid manager/clinician identities (see Hoque et al 2004). 
In addition to the interviews we engaged in substantial amounts of ethnographic research into the day-to-day behaviours of mid-level managers and clinician/managers inside these organizations. The objective was to understand the everyday conduct of NHS managerial work; the tasks and responsibilities middle and junior managers handle, how they act and behave, and how they feel about these actions and behaviours. A major theme to emerge from the research was the construction of managerialist ideologies and how they are (problematically) reproduced and distributed within public healthcare. In this respect, we have witnessed intense conflict in all four of the NHS organizations studied around new managerial interventions that are supposedly designed to improve efficiency and standards of care. Lean was used especially prominently at Milltown and as a result we focus on this particular case study in this paper. Below we provide more contextual detail about this organization.

Research site and process

Milltown Hospital currently employs over 4,000 staff, has approaching 1000 beds, and an annual income of just under $£ 200 \mathrm{~m}$. It offers secondary care across twentyplus medical specialisms (from A\&E to Urology). It was one of the first hospital Trusts to gain Foundation status and in recent years has received 'excellent' grades from the Care Quality Commission for standards of service and financial management. We spent 46 hours observing junior and middle managers as they went about their daily routines, noting and interpreting the details of both mundane and extraordinary events and behaviours. In addition, we carried out fourteen in-depth 
interviews with managers across middle and senior occupational levels which were digitally recorded and transcribed verbatim.

We spent considerable time observing training events aimed at mid-managers. These were important fora through which corporate communications about performance improvement measures, such as lean, were enacted and disseminated. At Milltown, there have been many lean-related training events held over recent years, and we attended four of these for the purposes of ethnographic observation and to recruit managers for subsequent interviews. Throughout these events, we adopted the role of semi-participant observers with the emphasis on observing rather than participating (for a similar approach in a similar setting see Hunter and Segrott 2014). We took extensive field notes on the official promotion, mid-management interpretation and 'usage', and the perceived impact and future of lean during these sessions, and wrote them up into more complete research accounts as soon as possible thereafter. We had no reason to believe that our presence at these training sessions affected much of what occurred in the sense of the Hawthorne Effect, even though at times we commented and joined in the practical sessions, such as class exercises and observational walks around wards. We have also interpreted a mass of printed and intranet-hosted material generated by the hospital, especially newsletters and PowerPoint presentation files.

We analysed this textual, observational, and sometimes visual data using an informal mode of thematic analysis (see McCann et al 2013: 758-9), whereby all authors would consider and re-read their own and each other's field notes, the secondary sources, and the interview transcripts. As a team we selected passages of data that most clearly explained and illuminated our three central research questions on how lean was 
promoted at the hospital, the ways in which mid-managers/clinicians claimed to have adopted and interpreted lean, and staff views on how the lean journey was progressing over time.

Our approach has been in keeping with the traditions of workplace ethnography (Tope et al 2005; Watson 1994; Watson 2011). Senior managers and consultants stake their claims and set an agenda, but this is not always 'bought into' in ways anticipated by other staff, perhaps especially where managerialist notions conflict with clinical professionals' understandings of patient and organizational 'needs'. Any processes of 'adoption' of management fashion are likely to be rhetorical, contested and deeply uncertain (Benders and van Veen 2001; Kieser 1997; Newell et al 2001; Schofield 2001), so in analysing both 'official' management-driven literature and presentations/training events on lean, our methodology aims to provide a scope broad enough to encompass these wide and often conflicting interpretations of lean in healthcare.

\section{Evidence and findings}

\section{Emerging from the 'Time Lag': How lean was promoted at Milltown}

Our first research question addresses the ways in which lean was promoted at the hospital. Lean adoption at Milltown followed national Department of Health policies. Locally lean was badged as the 'Milltown Improvement Programme' (MIP), and hospital management organized regular training events, many of them with assistance from a well-known manufacturing consultancy company. These local developments 
appeared to have emerged from the earlier 'Narrative Evolution' adoption phase (Birnbaum 2001: 129) where lean was promoted at higher government levels. MIP accordingly encompassed the mandated practices of 'value stream mapping', 'rapid improvement events', and the general encouragement of 'lean thinking' throughout the hospital. Substantial amounts of training, communications, and structured events were provided, with the hope of instilling lean thinking into the minds of all staff.

Staff newsletters regularly featured stories about MIP, and a separate newsletter just on MIP itself circulated the hospital: PowerPoint presentations from prior lean training events and 'roadshows' were made available on the Milltown intranet [4]. One of these presentations stated that MIP is part of the hospital's overall Organizational Development strategy. One of its slides featured a multicoloured circle of arrows moving clockwise, with various slogans around the perimeter, reading, 'Satisfied Staff, Loyal and Committed Staff, Staff that Support the Service Values, Satisfied Patients, Loyal Patients and Membership'. Moreover, MIP was shown to map directly onto the 'Milltown Wheel', which at one point was a significant ideological tool within the hospital. The Wheel (displayed frequently on posters around the various buildings, in training materials, and also appearing as a screen saver on every computer on the site) had in its centre the hospital's motto and was surrounded by various other managerialist slogans. Another staff newsletter twice used visual devices very similar to the so-called 'Toyota House', which lean advocates Liker and Morgan (2006: 6-7) claim 'has become a cultural icon in the manufacturing world'. The foot of this newsletter contained the very Womack-esque slogan 'seamless patient journey every time.' [5] 
These newsletters featured stories where lean had been successfully applied around the hospital, often including photographs of locations 'before' and 'after' lean. One example concerned patient information display on a particular ward. Prior to the lean event a whiteboard was in operation containing handwritten information on the occupants of the ward's 16 beds. After 'leaning' a new magnetic sign board was used by the nurses containing 8 standardized 'kanban'-style symbols for use across the hospital (a green circle for OT input, blue circle for physiotherapy input, a house for discharge, a yellow triangle for a fall, etc). The pictures show the new board looking tidier than the old and there seemed to be more space available for further information when needed. Photos of the old whiteboard show it as full with handwritten information, and rather messy and unprofessional in comparison. Other newsletters displayed similar 'lean' efforts of the midwives.

Mid-level managers provided favourable opinions of lean in some of our earlier interviews. For example a quality improvement manager (with a non-clinical background) stated in an interview that lean is 'a really fantastic tool'. Some of the managers with hybrid clinical/management roles (such as nurse managers or midwife managers) also gave supportive opinions in interviews. For example, one nurse manager portrayed lean as a language one could employ to try to encourage efficiency savings and better practice on the wards:

'If you go to your - if you engage your clinical staff, you are actually out there in your clinical areas engaging your staff, asking them their opinion, asking them what they think will make a difference. They actually come back with some really good ideas. And then if you talk to them about lean and say, "Well do you think we could use this methodology to make the change?" And they go: "Yeah, okay we're up for it. Yeah, we'll do it, we'll try it"."

[Interview, Senior Nurse Manager, Year 1 of study] 
There were signs, therefore, that lean had been well-received at ward level. But ther was always a question as to whether the described practices equated to genuinely 'lean' interventions. As another example, a newsletter reported five departments where lean changes have been made, and we reproduce an extract in Table One:

\section{INSERT TABLE ONE ABOUT HERE}

The laundry case was an interesting example of lean success that at least, partially, corresponded with the 'levelling down of demand' and 'pulling methodologies' of lean, as opposed to Fordist 'pushing'. 'Before lean' Laundry Services 'pushed' out clean bedding when it suited its staff, not when its customers (the wards) actually needed it. [6]

But the official documentation was sometimes ambiguous. One of the MIP newsletters states, for example: 'Nearly 100 years ago, Henry Ford took all the elements of a manufacturing system - people, machines, tooling \& products, \& arranged them into a continuous 'lean' system for manufacturing the Model T automobile. So we know it works.' Are we talking about lean or Fordism here? Throughout the selling of lean principles at Milltown there was significant ambivalence about the meaning of lean. 
Moreover our observations of Milltown also indicated many instances where lean promotion was unclear and problematic. Lean training events provided excellent opportunities to explore the 'selling' and 'buying' of lean in the hospital. One of these ran from $9 \mathrm{am}$ to $4 \mathrm{pm}$ in the education building of Milltown Hospital. We briefly describe the scene from our field notes:

'Jenny [pseudonym] the facilitator opened by mentioning the growth of MIP and that the session was an introduction to lean concepts. She mentioned 'the gold standard' and how lean is about a way of helping to achieve this. She said that you will have noted the rise of 'the MIP', the 'Productive Ward', and the 'Eight Week Lower-limb Pathway'. These policies are 'all based on lean principles'.

One of the first PowerPoint slides stated that lean comes from Japan and Toyota [...] 'they wanted to industrialize quickly but they had no space', Japan is 'quite small', 'an island', and they wanted to copy Ford but weren't able to do it with the 'huge warehouses' of Ford. [...] Someone mentioned 'it's a shame that it's Toyota' and made a wisecrack about the recent incident of faulty accelerator pedals. Jenny moved on to talk about the attempts to reduce inventory, as that is 'money sitting around doing nothing'. It's been: 'used in [UK supermarket] Tesco, for instance leaving the milk cartons on the trolleys which are wheeled right on the shop floor. Why waste time shelfstacking with milk cartons if the customers can just as well lift them off the trolleys? Morrison's do it also.' She went on to mention scanning your own items in Tesco and Sainsbury's which saves time for the shop and customer. The idea is to 'improve the process with what you've already got'. 'Start with a blank sheet'.'

[Field notes from observation of lean training roadshow, Year 1 of study]

In training events such as these staff appeared attracted (at a general level) to the principles of lean even when the principles were 'sold' in a somewhat 'folksy' manner such as above. Lean provided a legitimizing language which staff could adopt in order to make long-overdue, and fairly basic, changes and improvements to their working areas, such as the new patient status boards. The evidence shown of nurses and nurse managers clearing up and organizing storage areas looked like minor improvements. Such examples could be thought of as small victories for lean thinking 
at Milltown; the fad has been officially adopted and mid-level members of staff have added to the legitimation of the fad by claiming its utility. Lean was well into the 'Time Lag' phase and its ideological impact appeared considerable among many occupational groups. However, throughout the long process of lean training and adoption, there were many areas where problems with lean arose, as the lean life cycle at Milltown moved into Birnbaum’s ‘Narrative Devolution’ phase.

\section{Staff adoption and interpretation: The 'Narrative Devolution' of lean at Milltown}

The next question we were addressing related to how and why staff claimed to have adopted and interpreted lean. In doing so, was lean adapted and translated? Officially, lean had been adopted with some enthusiasm at Milltown, especially by the more general, i.e. non-clinical, managers who were largely 'selling' lean around the Trust. As demonstrated in the 'before and after' style events and outputs, lean did exist in some form at ward level. But the 'adoption' was often superficial. When lean training days were observed and when questioned about lean adoption in interviews, many of the mid-level managers (especially when they had dual managerial-clinical roles) were sceptical and were unsure that lean would present a solution. These staff regularly noted that their patients are not inanimate objects, but thinking, acting subjects, who behave unpredictably. Below is a typical example of how criticism of lean played out in a training day; questions ware handled in a friendly and open way by the facilitator, but were not really addressed or resolved.

'A questioning voice went up - one of the midwife/managers. 'Can this apply outside of supermarkets and car-making? We have a common problem with ladies who come in for elective caesareans. They come in one morning, there may be one [patient], they're in theatre, and discharged from the ward in a 
day. But on other times it can be confused and unpredictable. You might suddenly get two emergency procedures in theatre and the system starts to shake. [...] I understand the concepts, but our workload is not predictable, it's not as predictable as manufacturing. You get a backlog; like in A\&E. What comes in is what you get.'

There was some laughter as someone sarcastically suggests 'you can just wheel the patients in like the Tesco milk bottles on a pallet!'

'Yes, they are human beings', someone says.

The facilitator replied with: 'Yes, with A\&E you don't know what you're getting. But you have to work around that and think of ways to design systems that are robust. That's hard, certainly'.'

[Field notes from observation of lean training roadshow, Year 1 of study]

Further field observations illustrate the often feeble and superficial ways in which lean was defended by its promoters. A major part of a lean awareness day involved splitting the audience into two smaller groups and placing them on pre-arranged tours of other parts of the hospital. One group went to 'X-Ray 1' another to 'Outpatients 2'. After the visits comments about the practicalities and impracticalities of lean adoption were aired back in the classroom, in which lean essentially became 'watered down' (Brunsson 2006) or 'stretched' (Heusinkveld et al 2013) as a concept. As the following field notes suggest, almost anything that was felt to be effective or 'good' was said to be 'lean':

'A couple of midwives said that X-Ray 1 'was already pretty lean'. There was a consensus that the red line on the ground for patients to follow was good. 'It looked quite slick.' One thing people mentioned as 'not lean' was the need to transport the heavy X-ray plates into the room to have them analysed. It was mentioned that one of the Kodak X-ray reading machines was broken, and suggested that 'under lean conditions this wouldn't be tolerated'. Someone notes that the 2 year old patient with the fracture will need to be transported to another hospital - this was 'good' in that it showed 'efficient use of resources'. But in a lean system surely this patient should have been taken to [Children's Hospital] in the first place? The pink readout on the PC monitor was mentioned as an example of 'a visible kanban'. [...] Another midwife noted that there was a surveillance camera in the reception with a feed into a 
TV screen in the little X-ray room, so that staff could see if things were getting too busy outside. Was this lean? I noticed that there had been virtually no mention of kaizen and continuous improvement over the last couple of hours, which I thought was central to lean.'

[Field notes from observation of lean awareness event, Year 2 of study]

A deep problem kept resurfacing, of healthcare necessarily involving living, thinking, complex human beings rather than pieces of hardware, a point that even the champions of lean acknowledged at times:

'The manager running the lean awareness event mentioned X-Ray 1 and that the staff there who installed the red lines were said to be really thinking about 'the patient journey', but they noted that patients wouldn't actually follow the rules laid down. The line to follow on the ground will take you around the correct procedures in the right order, but patients didn't notice it, and there was a large sign hanging from the ceiling which people just walked past! 'They are nervous, going in for X-rays, they act oddly.'

[Field notes from observation of lean awareness event, Year 2 of study]

Although sometimes acknowledged, problems of this kind were rarely dealt with adequately. This is perhaps a result of fundamental mismatches between the (continuous improvement) concepts upon which lean is based, the sector in which it was primarily developed (automotive), and the location at which its application is being attempted (public healthcare). As a senior manager noted in an interview: lean is "reasonably well suited to back office functions, where the manufacturing logic is stronger, but not to those areas dealing with patients, which are more complex." A senior consultant who also held a managerial role suggested that lean is essentially incompatible with the complexities of professional medical practice:

'So they're following the national directives on how to address quality. Part of which, there's been a big push on Toyota and lean and all that kind of stuff, which I think has a place. [...] lean is about process. My work addresses clinical decision making and clinical guidelines. To implement clinical 
guidelines I'm not convinced that lean has a lot to offer. [...] [Decisions to take tests are] based on clinical judgement. When you've got the result, you've got to interpret it and that requires clinical judgement again. And acting on it requires clinical judgement.'

[Interview, Consultant Epidemiologist, Year 2 of study]

The ideological purchase of lean was not always strong, especially among senior clinician/managers who argued that lean had little to offer them given the complexity and professional judgement calls that their work entails. Moreover it often felt as if both the buyers and the sellers had doubts about the new system, and were somewhat 'going through the motions' of lean promotion. This supports Brunsson's (2006) notion of 'mechanisms of hope', and a central idea of much of the 'fads' literature in which new managerial concepts are deliberately vague to allow wide, but superficial, adoption (Benders and van Veen 2001). Beyond this, however, by conducting our research at Milltown over three years, we started to see evidence of a distinct decline of lean. It had gone from being 'a really fantastic tool', to something that 'has a place'. It is to this dynamic of late-stage 'fad life cycle' effects that we now turn.

Will the 'Lean Journey' continue? The limits of 'Dissonance Resolution'

This final section of our data analysis addresses our third research question: how was lean progressing longer-term at the Trust, and to what extent was it being embedded into everyday practice as senior management had intended? The prospects for longterm, meaningful adoption did not appear strong. Rather than becoming routine, criticisms of lean became more strident towards the end of our 3-year study of Milltown. For example, in an interview, a midwife/manager made the following comment: 
'There is no way in a million years the NHS is going to be lean. There's lots of lip-service to new ideas, but they can't actually happen. You get lots of kneejerk reactions. They go for the next big thing, but soon it'll be something else. It's like wheels within wheels.'

[Interview, Delivery Suite Operational Lead, Year 2 of study]

Based on years of NHS experience, she described lean as part of a 'succession' of management fads (Huczynski 1993); lean was the fashion of the day and was therefore not really worth engaging too strongly with. When faced with questions from participants, lean promoters often seemed incapable of 'resolving' this 'dissonance' (Birnbaum 2001). For example, when introducing 'the five whys' at a lean roadshow, a member of the audience asked a facilitator 'why ask five times?' The reply: 'It's a magic number.' The concept of lean became abstract and stretched, and lean 'champions' found it difficult to translate the concept into practical suggestions and modifications of lean and hence re-start or re-energise the fad life cycle. Difficulties were compounded when sellers themselves sometimes appeared to have limited real connection to the values of lean, as recorded in the following field note:

'Towards the end of the event, the structure of the session had broken down somewhat, and the facilitator was mingling with staff and informally discussing the issues. Talk turned to the accelerator pedals scandal at Toyota. One of the nurse managers said: 'Isn't it terrible that it's Toyota!?'

Facilitator: 'Yes, it is! We should change it to Honda or something. Or maybe just "Japan."

[Field notes from observation of rapid improvement event, Year 2 of study]

Lean roadshows and training days were repeatedly held during our three years of research at Milltown, not just at the beginning of the 'implementation'. Yet the sense of doubt and unreality regarding lean adoption did not diminish over time. Supporters 
of lean (whether buyers or sellers) sometimes made lean look absurd when attributing almost any kind of minor improvement as an example of 'leaning'. This stretching of the concept to illogical proportions (see Heusinkveld et al 2013) suggests a lack of real ideological commitment to lean as a concept, even among the champions. A striking example was when a lean champion explained how one department had 'leaned a room':

'This was a former WRVS cafe, old and very uninviting, but which has now been taken over by the department and improved. They got rid of the old plastic flowers and made the best of the room. There used to be a light fitting in this room that was on too long a cord, and people kept banging their heads on the light. So they leaned the room, and got an electrician to install a shorter cord. They wanted to make it more like a dentist's, nice and tidy, with leaflets that were well-stacked. The room was made more standardized - clean, with new signs'.

[Field notes from observation of lean awareness roadshow, Year 3 of study]

Moreover, interview data gathered during the later stages of our research indicated that the policy of lean adoption was being reviewed and quietly withdrawn. There was scepticism about lean at senior levels of the hospital, particularly among clinical professionals who had taken on senior management roles but tended to be dismissive of managerialist fads (for a similar dynamic see Hoque et al 2004). For example, a senior clinician/manager, raised several concerns in an interview, and it was noted that lean was becoming progressively invisible. There were few signs of a Dissonance Resolution that might re-start the life cycle (Birnbaum 2000: 7):

'I think the lean initiative here was probably very popular, I would say, probably a couple of years ago, I would say it was at its peak where, you know, you'd hardly go to a meeting without somebody mentioning lean [...]. I think, the trouble with the concept was that you could take 20 people out of their workplace and then they could spend three days in the room talking about it $[\ldots]$. But the notion that you could have 20 people in a room sticking 
sticky Post-Its on a wall and then re-arrange them all and come out with a miraculous solution, I'm not sure I saw it really deliver that well [...]. When you're in a busy hospital where there's nobody who has got a spare minute, saying we're just going to take everyone to one side, and reinvent this process was, I think, hard [...]. The way they were selling it was, you know, every physio that's involved would be in there, every nurse would be in there, every doctor, you know, you just can't [...]. You haven't got the luxury of that kind of manpower for projects [...]. I've not heard much mention of lean for the last six months [...]. The things that seemed to be improved seemed to be relatively trivial, you know, "we've looked at the medical records office and tidied it up a little bit." You know, "we found the stapler that used to be over there is now over here", you know, that kind of thing, which is all well and good. I'm not sure it's world changing and, I think [...] it was a fashion that hasn't necessarily embedded as a routine process'.

[Interview, Senior Clinical Manager, Year 3 of study]

Similarly critical comments were made during observations of a subsequent project evaluation meeting that took place at the end of our three years studying Milltown. Middle managers from across the hospital made the following comments at different points in the meeting, which were recorded in our field notes. Here we see more of a temporal dimension to our analysis, in that the respondents are talking about lean in the past tense. It was something they had tried, but that they discovered to have been of limited value, and is now in decline; indicative of the end stages of the fad life cycle as discussed by Birnbaum and others:

'We used lean in Radiography and found that while the throughput of patients was better it led to more mistakes with people-checking. So the two seemed to cancel each other out'.

$[\ldots]$

'People are a lot more positive about Lean if they have that term in their [job] title. But generally it has become a lot less visible in the last couple of years.'

$[\ldots]$

'Lean is an innovation that is not really appropriate in the NHS'

[Field notes from observation of project evaluation meeting, Year 3 of study] 
In the final few weeks of our engagement with the hospital, we noticed that even the Milltown 'Wheel' screen savers - a prominent expression of the lean campaign - had been removed from staff PCs. This seemed to signify that the 'lean journey' had come full-circle, the fad life cycle had run its course, and that the "wheels had come off' this particular management fashion. At the time of writing, no apparent effort was being made to re-start the cycle.

\section{Conclusions}

Birnbaum, in his book on fads in higher education, noted that 'the management of some non-academic professional institutions, such as churches, hospitals, and research laboratories, may more closely resemble the university than the business corporation' (2001: 125). Professional bureaucracies are likely to operate with 'deeply embedded' norms or 'entrenched practices' (Carson et al 2000: 1143) which can restrict the uptake of supposedly universal reforms developed in the corporate sector. Waring and Bishop (2010: 1339), in their conclusion to one of the first case studies on lean adoption in the NHS, speculated that it is 'a highly contested process' that is 'unlikely

to survive translation to practice fully intact' (2010: 1339). Our observations at Milltown strongly validate that position. Indeed we go further. In our case, at least, lean may not have any realistic future.

Why was the adoption so fragile? At Milltown, there was initially quite strong enthusiasm for lean among both sellers and some of the buyers. Buyers (especially ward-level manager/clinicians such as nurse managers) used the language of lean to try to 'get things done' at the hospital. But many of these interventions were 
superficial both in their impact and in their connection to lean. The lack of genuine progress in the hospital led to lean appearing weak, pliable, and superficial. As sellers and buyers both started to stretch the meaning of lean, critical and sceptical voices became louder at Milltown, leading to the eventual erosion of lean as a viable concept. Lean at the hospital faded from view not so much because it became "worn out through use' (Benders and van Veen 2001), but because it became increasingly weak and ephemeral as its rhetorical use spread into untenable domains.

Ultimately the shift to illogicality undermined lean fatally, both as an effective 'gold standard' management technology and also in its more limited, informal, utility as a 'mechanism of hope' (Brunsson 2006). The 'reality' of lean adoption at Milltown was increasingly 'decoupled' (Heusinkveld et al 2013) from primary concepts. This saw lean ultimately fall into a state of being a superficial, largely rhetorical, phenomenon (Birnbaum 2000: 11-12); just another in a 'succession' (Huczinski 1993) of NHS management fads.

Our findings mirror some of the complex dynamics of hope, trust, expectation and disappointment surrounding lean adoption as demonstrated in prior work by Milkman (1997) and Graham (1995) on the upgrading of car plants in the United States. Much like our hospital staff, many operators at GM Linden and Subaru-Isuzu Indiana initially reacted with excitement about lean - especially as a way of finally resolving age-old frustrations with prior work systems - before becoming disaffected as so many of the age-old problems resurfaced. Whether the promise of lean elsewhere in the NHS will be realised in the future is very much an open question. Staff and managers' reservations about lean surfaced readily in our study, but we are wary of 
the dangers of extrapolating from one case. Nevertheless, our research suggests reasons to be sceptical about the value and sustainability of lean in UK healthcare, for it strongly reinforces classic arguments on the nature of fad life cycles. Indeed, signs of Birnbaum's final stage of the life cycle, that of 'Resolution of Dissonance', are starting to appear in the pro-lean literature. Lean promoters are now arguing that the NHS and other public sector organizations have made the mistake of adopting lean in an isolated 'tool-like', rather than 'system-wide', fashion (Radnor et al 2012; Radnor and Osborne 2013). Such a manoeuvre suggests that there is nothing wrong with lean itself, but that problems in public sector organizations are more to do with inadequate local adoption - a classic argument used to try to restart fad life cycles.

As part of a larger study into managerial work and organizational change in the NHS, the findings of this case study research into lean adoption at one particular NHS site cast doubt about the wisdom and traction of lean adoption in healthcare. Lean was widely promoted by senior management at Milltown and there was some evidence that its concepts may have influenced efforts to reduce waste and improve clarity in basic administrative and functional tasks. There was some initial enthusiasm for lean among several of the occupational groups at mid-management level, even as lean was often 'sold' in a rather basic fashion. While not hostile to lean, staff tended to interpret it in a similarly superficial manner, in which almost any form of 'improvement' (from tidying shelves to reorganizing signage) were labelled as part of these lean initiatives, drawing on the ideological language that was circulating the Trust at this time. However, as our investigations continued, we found that this somewhat basic and superficial lean adoption was not sustainable - if everything became lean, then lean became nothing. The case study does not support the 
'humanitarian critique' of lean; unlike Carter et al.'s studies (2011, 2013) lean adoption at Milltown did not appear to have led to work intensification or deprofessionalization. Nor did it fulfil the promise of a revolutionary improvement in systems and efficiency (Fillingham 2007; Radnor et al 2013). In the final analysis, lean adoption at the hospital was fragile and feeble. Echoing the findings of Waring and Bishop (2010), NHS lean adoption was highly ritualistic. More than this, our particular case study suggests that lean at the hospital has progressed through a prototypical fad life cycle, passing beyond ritual and into obscurity.

Ultimately the adoption of lean at Milltown was not as sophisticated or totalizing as it has been in the global automotive industries. Stewart et al (2009: 10) argue that lean has allowed employers to reach 'checkmate' with workers and unions and removed all of their discretion and voice (similar arguments are made by Carter et al about lean adoption in the UK civil service; Carter et al 2011, 2013). Clearly this has not happened at Milltown, where the adoption of lean has been much more fragmented and contradictory. It can be ignored by professional clinical workers who are uninterested or resistant, and the sellers of lean often seem unable to fully draw the sting of staff critique or find ways to re-energise lean adoption.

In practical terms, our findings suggest that there are areas of Milltown Hospital that could benefit from interventions that have some resemblance to lean operations. But the use of lean to achieve this in a wholesale, messianic fashion is nonsensical. There could be scope for piecemeal changes, motivated by distinct, practical bottlenecks that could be ameliorated with some attention to detail. In fact something like this is already happening in some areas of Milltown, and has probably been going on for 
some time as the hospital has acknowledged continual and long-standing cost-control pressures. A culture whereby suggestions from staff are genuinely considered, discussed and adopted would be advantageous. But there are, of course, major practical barriers to such a system being adopted; such as heavy workloads and insufficient resources, the inability to take staff 'off the line' for meetings and training, information overload, and a general feeling among health professionals that managerialist innovations such as lean are simply inappropriate for complex and human-centred healthcare workplaces. We suggest that the goal of some kind of lean revolution - of a wholesale lean 'system-level' adoption (Radnor et al 2013) - at Milltown is unrealistic for both the sellers and buyers of lean, and that there remains considerable value in revisiting the concept of the 'fad life cycle' in an effort to understand the contested reality of lean adoption in public sector settings.

\section{Acknowledgements}

The authors would like to thank the many managers and staff who helped to facilitate our research at the (anonymous) NHS Foundation Trust, as well as the Associate Editor and anonymous referees at Human Relations whose constructive criticism helped to sharpen out arguments.

\section{Funding}

This paper is derived from a wider research study entitled 'Roles and Behaviours of Middle and Junior Managers: Managing New Organisational Forms of Healthcare', funded by the NIHR Service Delivery and Organisation Programme (project number 08/1808/241). 
Notes

[1] There is also a large literature suggesting huge variation still exists in terms of 'best practice' in car manufacturing across the world. TPS has traditionally worked well for Toyota but is not readily exportable (Williams et al 1994; see also literature by the GERPISA network www.gerpisa.org/en)

[2] The rather managerialist authors Carson et al (2000: 1145) and Ettore (1997) suggest simpler but similar models to Birnbaum's. Carson et al present a 4-step model of 'invention, acceptance, disenchantment and decline', and Ettore a 5-step model of 'Discovery, Wild Acceptance, Digestion, Disillusionment, and Hard Core.'

[3] NIHR Service Delivery and Organisation Programme (project number 08/1808/241). Disclaimer: The views and opinions expressed therein are those of the authors and do not necessarily reflect those of the NIHR SDO programme of the Department of Health.

[4] Secondary data quoted throughout the paper are taken from various Milltown sources, including newsletters and PowerPoint slides. To protect the Trust's anonymity, we have not included reference to specific documents or page numbers.

[5] Incidentally Radnor (2010: 425) has produced a similar-looking 'framework' known as 'House of Lean for Public Services.' 
[6] On closer inspection, even this example is somewhat questionable. The lean manufacturing literature argues that 'pulling' is driven by the specifics of customer demand, yet many of the 'processes' and 'outputs' in the hospital by their nature cannot be customizable.

\section{References}

Abrahamson, E., (1991) 'Managerial Fads and Fashions: The Diffusion and Rejection of Innovations', Academy of Management Review, 16, 3: 586-612

Abrahamson, E., (1996) 'Management Fashion', Academy of Management Review, 21, 1: 254-285

Abrahamson, E., and Fairchild, G., (1999) 'Management Fashion: Lifecycles, Triggers, and Collective Learning Processes', Administrative Science Quarterly, 44: 708-740

Bell, D., (1973) The Coming of the Post-Industrial Society: A Venture in Social Forecasting, New York: Basic Books

Benders, J., and van Bijsterveld, M., (2000) 'Leaning on Lean: The Reception of a Management Fashion in Germany', New Technology, Work, and Employment, 15, 1: $50-64$

Benders, J, and van Veen, K., (2001) 'What's in a Fashion? Interpretative Viability and Management Fashions', Organization, 8, 1: 33-53

Beynon, H., (1986) Working for Ford, Harmondsworth: Penguin

Birnbaum, R., (2000) 'The Life Cycle of Academic Management Fads', The Journal of Higher Education, 71,1: 1-16

Birnbaum, R. (2001) Management Fads in Higher Education: Where they come from, what they do, why they fail, New York: Jossey-Bass

Brunsson, N., (2006) Mechanisms of Hope: Maintaining the Dream of the Rational Organization, Copenhagen: Copenhagen Business School Press

Brunsson, N., (2009) Reform as Routine: Organizational Change and Stability in the Modern World, Oxford: Oxford University Press

Caldwell, C., Brexler, J., and Jennyen, C., (2005) Lean-Six Sigma for Healthcare: A Senior Leader Guide to Improving Cost and Throughput, Milwaukee: Quality Press 
Carson, P.C., Lanier, P.A., Carson, K.D., and Birkenmeier, B.J., (1999) 'A historical perspective on fad adoption and abandonment', Journal of Management History, 5, 6: 320-333

Carson, P.C., Lanier, P.A., Carson, K.D., and Guidry, B.N., (2000) 'Clearing a Path through the Management Fashion Jungle: Some Preliminary Trailblazing', Academy of Management Journal, 43, 6: 1143-1158

Carter, B., Danford, A., Howcroft, D., Richardson, H., Smith, A., and Taylor, P., (2011) 'All they lack is a chain': lean and new performance management in the British civil service', New Technology, Work and Employment, 26, 2: 83-97

Carter, B., Danford, A., Howcroft, D., Richardson, H., Smith, A., and Taylor, P., (2013), 'Taxing Times: Lean Working and the Creation of (In)efficiencies in HM Revenue and Customs', Public Administration, 91,1: 83-97

Castells, M., (2000) The Rise of the Network Society, $2^{\text {nd }}$ edition, Oxford: Blackwell

Christopher, M., (2004) Logistics and Supply Chain Management, London: FT Prentice Hall, $3^{\text {rd }}$ edition

Collins, D., (2000) Management Fads and Buzzwords: Critical-Practical Perspectives, London: Routledge

Coffey, D., (2006) The Myth of Japanese Efficiency, Cheltenham: Edward Elgar

Danford, A., (1998) 'Work Organisation Inside Japanese Firms in South Wales: A Break from Taylorism?' in Thompson, P., and Warhurst, C., eds., Workplaces of the Future, Basingstoke: Palgrave

de Cock, C., and Hipkin, I., (1997) 'TQM and BPR: Beyond the Beyond Myth', Journal of Management Studies, 34, 5: 659-675

Delbridge, R., (1998) Life on the Line in Contemporary Manufacturing: The Workplace Experience of Lean Production and the 'Japanese' Model, Oxford: Oxford University Press

Eaton, M., and Phillips, S., (2008) Sustaining Lean Healthcare Programmes: A Practical Survival Guide, St Albans: Ecadmey Press

Ettore, B., (1997) 'What's the Next Business Buzzword?', Management Review, 86. 8: $33-35$

Fillingham, D., (2007) 'Can lean save lives?' Leadership in Health Services, 20: 231241

Furnham, A., (2004) Management and Myths: Challenging business fads, fallacies and fashions, Basingstoke: Palgrave 
Gibson, J.W., and Tesome, D.V., (2001) 'Management fads: Emergence, evolution, and implications for managers', Academy of Management Executive, 15, 4: 122-133

Graban, M., (2008) Lean Hospitals: Improving Quality, Patient Safety, and Employee Satisfaction, New York: Taylor \& Francis Group

Graham, L., (1995) On the Line at Subaru-Isuzu, Ithaca: Cornell University Press

Grint, K., and Case, P., (2000) 'Now where were we? BPR Lotus-eaters and Corporate Amnesia', in Knights D, and Willmott, H., eds., The Reengineering Revolution: Critical Studies of Corporate Change, London: Sage

Heusinkveld, S., Benders, J., and Hillebrand, B., (2013) 'Stretching Concepts: The Role of Competing Pressures and Decoupling in the Evolution of Organization Concepts', Organization Studies, 34, 1: 7-32

Hoque, K., Davis, S., and Humphreys, M., (2004) 'Freedom to do what you are told: Senior management team autonomy in an NHS acute trust', Public Administration, 82, 2: $355-375$

Huczynski, A.A., (1993) 'Explaining the succession of management fads', The International Journal of Human Resource Management, 4, 2: 443-463

Hunter, B., and Segrott, J. (2014) 'Renegotiating inter-professional boundaries in maternity care: implementing a clinical pathway for normal labour', Sociology of Health \& Illness, 36, 5: 719-737

Kamata, S., (1983) Japan in the Passing Lane: An Insider's Account of Life in a Japanese Auto Factory, London: Allen \& Unwin

Keulen, S., and Kroeze, R., (2012) 'Understanding management gurus and historical narratives: The benefits of a historic turn in management and organization studies', Management \& Organizational History, 7, 2: 171-189

Kieser A., (1997) 'Rhetoric and Myth in Management Fashion', Organization, 4,1: 49-74

Krause-Jensen, J., (2011) 'Ideology at work: Ambiguity and irony of value-based management in Bang and Olufsen', Ethnography, 12, 2: 266-289

Liker, J.K., (2004) The Toyota Way, New York: McGraw-Hill

Liker, J.K. and Morgan, J.M., (2006) 'The Toyota Way in Services: The Case of Lean Product Development' Academy of Management Perspectives, 20: 5-20

Liker, J.K., and Hoseus, M., (2007) Toyota Culture: The Heart and Soul of the Toyota Way, New York: McGraw-Hill 
McCann, L., Granter, E., Hyde, P., and Hassard, J., (2013) 'Still Blue-Collar after all these Years? An Ethnography of the Professionalization of Emergency Ambulance Work', Journal of Management Studies, 50, 5: 750-776

Marcus, A.I., (2008) ''Would you like fries with that, Sir?' The evolution of management theories and the rise and fall of total quality management within the American federal government', Management and Organizational History, 3, 3/4: 311338

Maxton, G.P., and Wormald, J., (2004) Time for a Model Change: Re-engineering the Global Automotive Industry, Cambridge: Cambridge University Press

Milkman, R., (1997) Farewell to the Factory: Auto Workers in the late twentieth century, Berkeley: University of California Press

Mills, J.H., Dye, K., and Mills, A.J., (2009) Understanding Organizational Change, Abingdon: Routledge

Mehri, D., (2005) Notes From Toyota-Land: An American Engineer in Japan, Ithaca: Cornell University Press

Mehri, D., (2006) 'The Darker Side of Lean', Academy of Management Perspectives, 20, 2: 21-42

Mouer, R., and Kawanishi, H., (2005) A Sociology of Work in Japan, Cambridge: Cambridge University Press

Newell, S., Robertson, M., and Swan, J., (2001) 'Management fads and fashions', Organization, 8,1: 5-15

Parker, L.D., and Ritson, P., (2005) 'Fads, stereotypes and management gurus: Fayol and Follett today', Management Decision, 43, 10: 1335-1357

Piore, M.J, and Sabel, C.F., (1984) The Second Industrial Divide: Possibilities for Prosperity, New York: Basic Books

Radnor, Z., (2010) 'Transferring Lean into Government', Journal of Manufacturing Technology Management, 21, 3: 411-428

Radnor, Z., Walley, P., Stephens, A., and Bucci, G., (2006) 'Evaluation of the Lean Approach to Business and Management and its use in the Public Sector', Office of the Chief Researcher, Scottish Executive, Edinburgh

Radnor, Z., Holweg, M., and Waring, J., (2012) 'Lean in healthcare: The unfulfilled promise?', Social Science \& Medicine, 74, 3: 364-371

Radnor, Z., and Osborne, S.P., (2013) 'Lean: A failed theory for public services?', Public Management Review, 15, 2: 265-287 
Schofield, J., (2001) 'The Old Ways are the Best? The Durability and Usefulness of Bureaucracy in Public Sector Management', Organization, 8,1: 77-66

Shapiro, E.C., (1998) Fad Surfing in the Boardroom: Reclaiming the courage to manage in the age of instant answers, Oxford: Capstone

Stamatis, D.H., (2010) Essentials for the Improvement of Healthcare using Lean and Six Sigma, Florence, KT: Productivity Press

Stewart, P., Murphy, K., Danford, A., Richardson, T., Richardson, M., and Wass, V., (2009) We Sell Our Time No More: Workers' Struggles against Lean Production, London: Pluto

Sturdy, A., (2004) 'The Adoption of Management Ideas and Practices', Management Learning, 35, 2: 155-179

Tamura, Y., (2006) 'Japanese Production Management and Improvements in Standard Operations: Taylorism, Corrected Taylorism, or Otherwise?', Asian Business \& Management, 5, 4: 507-527

Tope, D., Chamberlain, L.J., Crowley, M., and Hodson, R. (2005). 'The benefits of being there: Evidence from the Literature on Work'. Journal of Contemporary Ethnography, 34, 470-493

Waring, J.J., and Bishop. S. (2010) 'Lean healthcare: Rhetoric, Ritual, Resistance', Sociology of Health \& Illness, 33, 5: 661-676

Watson, T.J. (1994) 'Management "flavours of the month": their role in managers' lives', The International Journal of Human Resource Management, 5, 4: 893-909

Watson, T. J., (2011) 'Ethnography, reality and truth: the vital need for studies of 'how things work' in organisations and management'. Journal of Management Studies, 48, 202-217

Wickens, P.D., (1993) 'Lean Production and Beyond: The System, Its Critics and the Future', Human Resource Management Journal, 3, 4: 75-90

Williams, K., Haslam, C., Johal, S., and Williams, J., (1994) Cars: Analysis, History, Cases, Providence: Berghahn Books

Womack, J.P., and Jones, D.T., (1996) Lean Thinking: Banish Waste and Create Wealth in your Corporation, London: Simon and Shuster

Womack, J.P., Jones, D.T., and Roos, D., (1990/2007) The Machine that Changed the World, London: Simon and Shuster 